\title{
PLATELET-RICH FIBRIN USED AS A SCAFFOLD IN PULP REGENERATION: CASE SERIES
}

\begin{abstract}
Regenerative endodontic treatment (RET) is a biologically-based treatment approach aimed at providing root development and improving the prognosis of teeth. The purpose of this case series was to evaluate the clinical and radiological results of RET using platelet-rich fibrin (PRF) in 4 immature teeth with necrotic pulps. At the end of a 1824-month follow-up, no clinical symptoms were recorded. Apical closure was observed in 3 of the 4 teeth. All of the preoperative periapical lesions were healed. However, a calcified tissue formed in the middle third of the root in one case diagnosed with chronic apical periodontitis at the 3-month follow-up. PRF was successful as a scaffold and can be recommended for revascularization protocol of necrotic immature teeth. However, the prognosis of tooth can be attributed to many factors such as the duration of pulp necrosis, pretreatment status of the periapical region, and the viability of living tissues.
\end{abstract}

Keywords: Immature teeth, platelet-rich fibrin, pulp necrosis, pulp regeneration, scaffold.
*Ceren Çimen $^{1}$

(D) Selin Şen ${ }^{1}$

(D) Elif Şenay ${ }^{1}$

(D) Tuğba Bezgin ${ }^{1}$

\section{ORCID IDs of the authors: \\ C.Ç. 0000-0002-0641-0831 \\ S.Ş. $\quad 0000-0002-3301-9651$ \\ E.Ş. $\quad 0000-0002-9150-4997$ \\ T.B. 0000-0002-3025-308X}

${ }^{1}$ Department of Pediatric Dentistry, Faculty of Dentistry, Ankara University, Ankara, Turkey.

$\begin{array}{ll}\text { Received } & : 02.12 .2020 \\ \text { Accepted } & : 12.01 .2021\end{array}$ 


\section{INTRODUCTION}

Regenerative endodontic treatment is a series of procedures aimed at restoring the function of dentin, root, and pulp-dentin complex damaged by trauma or caries by the transplantation or the stimulation of stem cells into the root canal., ${ }^{1,2}$ Galler ${ }^{1}$ reported the advantages of regenerative endodontic treatments over calcium hydroxide apexification and MTA apexification as (i) immuno-response and interstitial tissue pressure against invading bacteria and toxins, (ii) pain perception as a warning system, (iii) completion of root formation in young patients to strengthen thin dentine walls and prevent long-term complications, and (iv) the restoration of sound periradicular tissues.

Regenerative endodontic treatment includes the procedures of disinfecting the root canal, formation of a suitable tissue scaffold, providing support for the newly formed tissues, and sealing the root canal with a biomaterial. ${ }^{1-4}$

Tissue scaffold formation is achieved by inducing bleeding into the root canal in current regenerative endodontic treatment procedures. $^{4}$ However, the procedure may have certain drawbacks such as failure to initiate bleeding or inadequate bleeding in the root canal. Another disadvantage of apical bleeding is the injury of the periapical tissues during the push and pull motion of the file. ${ }^{5-7}$ Recent studies have reported that the use of autologous fibrin matrices (Platelet-rich plasma-PRP, Platelet-rich fibrin-PRF) as a tissue scaffold produced promising results in clinical and radiological examination. ${ }^{6,8-12}$ Platelet concentrates are blood-derived products in which the platelets are concentrated in a limited volume of plasma. ${ }^{13}$ Although the blood clot contains more stem cells as it is obtained by bleeding the periapical tissues, there are more healing factors in matrices such as PRP and PRF. ${ }^{10,13}$ PRF is prepared by the centrifugation of venous blood for once without the need for an anticoagulant material. ${ }^{13}$ As it contains more immune cells than blood clot and PRP, PRF is reported to be more efficient in controlling the infection. ${ }^{10,13}$ Moreover, compared to PRP, the slower release of growth factors of PRF is congruous to the healing pattern of pulp-dentin complex. ${ }^{2,9}$ However, there is a limited number of cases in the literature in which PRF is used as a tissue scaffold. ${ }^{9,11,14-18}$

The purpose of this case series is to present the long-term follow-up of regenerative endodontic treatments using PRF tissue scaffold in four necrotic immature permanent teeth.

\section{CASE REPORTS}

\section{Case report 1}

An 8-year-old male patient with night pain was referred to the Department of Pediatric Dentistry. The patient had no significant medical history. Dental anamnesis revealed that he had fell down at school 4 days earlier, fracturing right maxillary incisor tooth. The tooth was restored in a clinic a day after the trauma; however, it was reported that spontaneous pain started the same night. The clinical examination revealed a composite resin restoration in the tooth (Figure 1a).

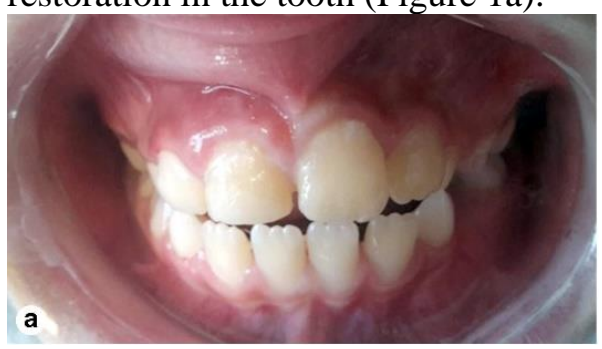

Figure 1a: Preoperative view of Case 1

There was positive response to percussion and palpation, and lingering pain response to electric (Digitest; Parkell, Farmingdale, NY, USA) and cold sensitivity tests (Chloraethyl, Wehr, Baden, Germany). Periodontal probing was within normal limits. Radiographic examination revealed an immature root with an open apex but no evidence of periapical rarefaction. (Figure 1b).

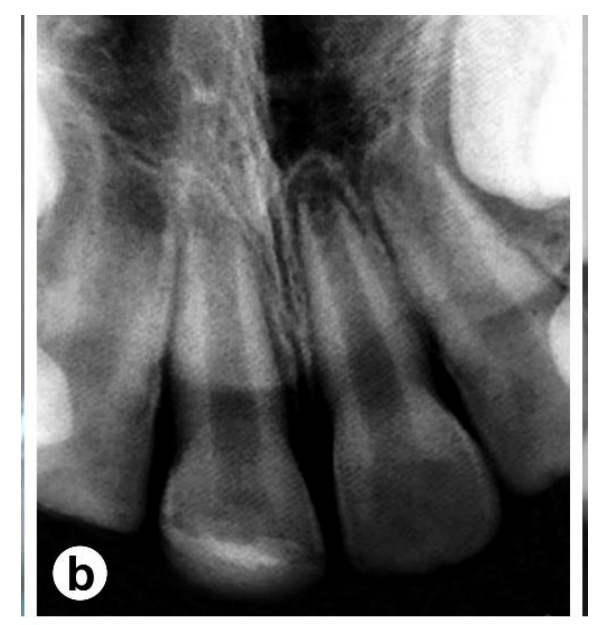

Figure 1b: Preoperative radiograph showing incompletely developed apex. 
The tooth was diagnosed with acute apical periodontitis.

After informing the patient and his parents about the treatment modalities, regenerative endodontic treatment using PRF scaffold was planned. The American Association of Endodontists protocol was used as described below. Following the application of local anesthesia (2\% lidocaine containing 1:100,000 epinephrine), the tooth was isolated with a rubber dam and the access cavity was prepared. The root canal was irrigated gently with $20 \mathrm{~mL} 1.5 \%$ sodium hypochlorite $(\mathrm{NaOCl})$ solution followed by $20 \mathrm{~mL}$ sterile saline. The root canal was then dried with paper points. Equal proportions of ciprofloxacin (Cipro Biofarma, Istanbul, Turkey) and metronidazole (Flagyl Eczacibasi, Istanbul, Turkey) were ground and mixed with sterile saline to form a paste with a concentration of $0.1 \mathrm{mg} / \mathrm{ml}$. This antibiotic paste was placed in the root canal below the cementoenamel junction by using a dental syringe. The access cavity was temporarily sealed with a sterile cotton pellet and restorative glass ionomer cement (Ionofil, Voco, Cuxhaven, Germany). After 3 weeks, the patient was asymptomatic. The tooth was anesthetized using mepivacaine without vasoconstrictor. After applying a rubber dam, the access cavity was reopened, the antibiotic mixture was removed by irrigation with $20 \mathrm{~mL}$ sterile saline, $20 \mathrm{~mL} 17 \%$ EDTA following by $5 \mathrm{~mL}$ sterile saline and the root canal was dried with paper points.

For the PRF preparation, $10 \mathrm{~mL}$ of the patient's venous blood was collected in sterile tubes. The tubes were centrifuged for 10 minutes with a speed of 3,000 rpm. The fibrin matrix formed after centrifugation was taken from the tube and placed up to $2-3 \mathrm{~mm}$ apical of the cementoenamel junction with the help of a handpiece. The access cavity was then sealed with Biodentin (Septodont, Saint Maur des Faussés, France) and the tooth was permanently restored with reinforced glass ionomer cement (Ketac TM Molar Easymix, 3M ESPE, Seefeld, Germany) and composite resin (Clearfil Majesty, Kuraray, Japan) (Figure 1c).

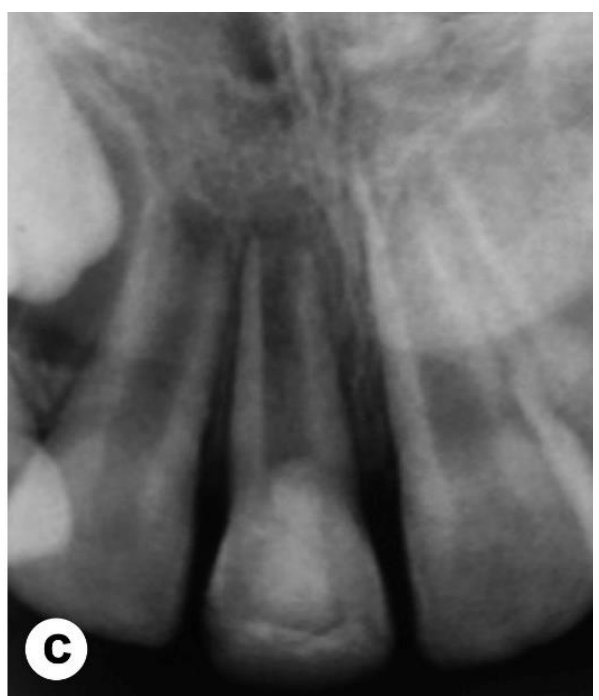

Figure 1c: The immediate post-treatment periapical radiograph

The patient was followed up regularly (Figure 1dh). In the clinical and radiological controls, no symptoms were recorded, the periodontium was radiographically normal and apical closure was observed at the 18th month control. The patient is scheduled for further follow-up.

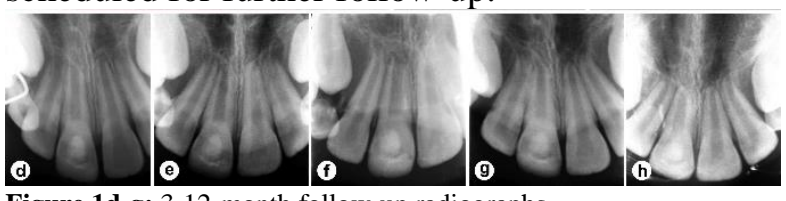

Figure 1d-g: 3-12-month follow-up radiographs

Figure 1h: At the 18-month follow-up, apical closure was evident

\section{Case Report 2}

A 9-year-old girl consulted to the Department of Pediatric Dentistry with the complaint of swelling in gums and pain. She had no significant medical history. The patient had a bicycle accident a year earlier, fracturing Tooth \#11 which was restored 3 times in different dental clinics in one year. Intraoral examination revealed abscess formation in the gum and positive response in percussion and palpation at Tooth \#11 (Figure 2a).

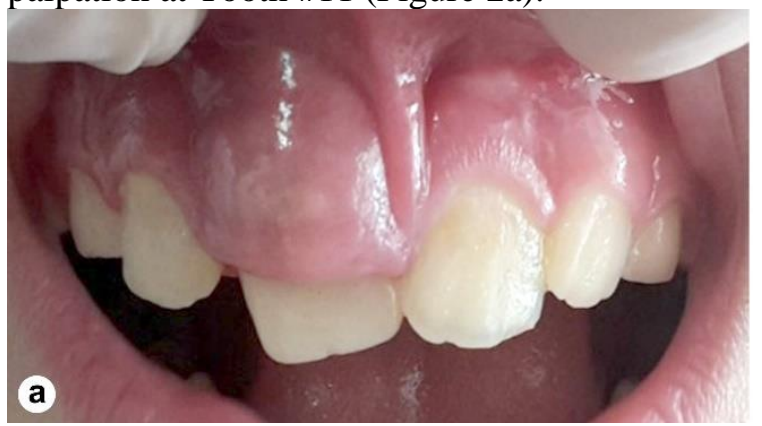

Figure 2a: Preoperative view of Case 2 showing an abscess formation in the gum of Tooth \#11

Radiographic examination revealed the presence of a large periapical lesion with an immature root and an open apex (Figure 2b). The tooth was diagnosed 
with acute apical abscess.

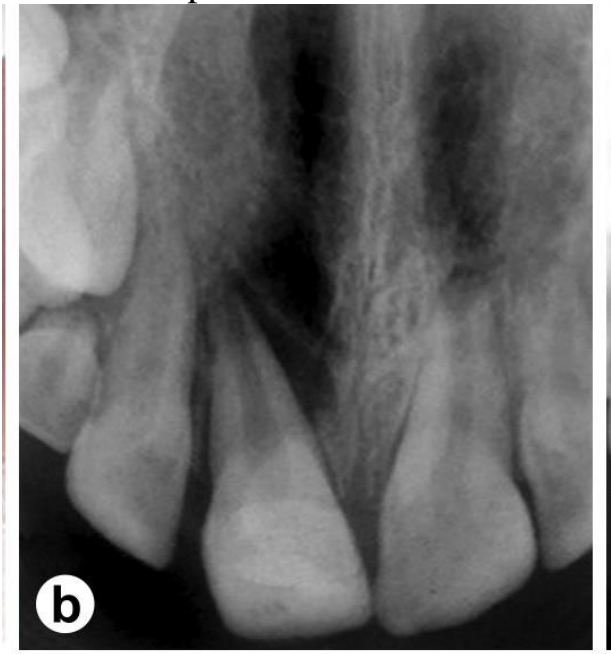

Figure 2b: Preoperative radiograph of Tooth \#11 revealed the presence of a large periapical lesion with an immature root and an open apex

The patient and her parents were informed about treatment options and revascularization was planned by using PRF tissue scaffold. At first appointment, the access cavity was prepared, pus flow was provided through the root canal and the intraoral abscess was drained through the gum pocket. The root canal was irrigated with sterile saline and the tooth was sealed with a cotton pellet and Cavit (3M ESPE, Seefeld, Germany). The patient was recalled 2 days later and it was observed that the drainage of pus from the root canal stopped. The revascularization protocol was performed as specified in Case 1 (Figure 2c).

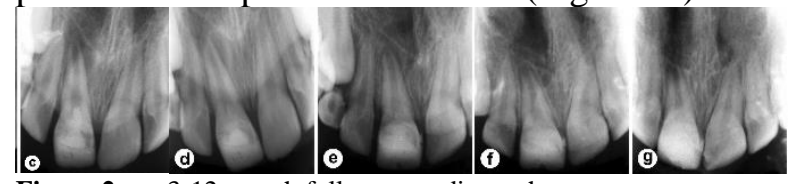

Figure 2c-g: 3-12-month follow-up radiographs

The patient was followed up regularly after the treatment (Figure 2d-h).

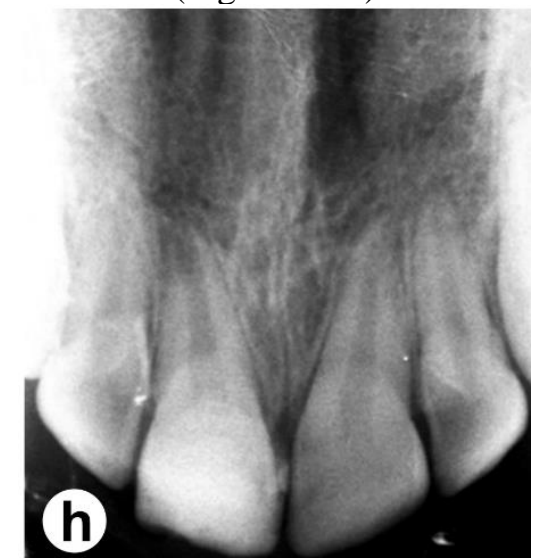

Figure 2h: At 18 months, complete healing of the periapical lesion can be appreciated, however no apical closure was observed.
Although the tooth functioned asymptomatically and radiographic healing at periapical lesion was present at the 12th month, apical closure has not been observed at the end of the 18th month. The patient's follow-up is still ongoing.

\section{Case Report 3}

A 9-year-old girl was referred to our clinic due to a fracture of the filling in the anterior tooth. The patient had no significant medical history. Her right maxillary incisor tooth was fractured in a bike accident 6 months earlier and the tooth was restored in a private clinic. Intraoral examination revealed that there were residues of pulp capping material on Tooth \#11 (Figure 3a).

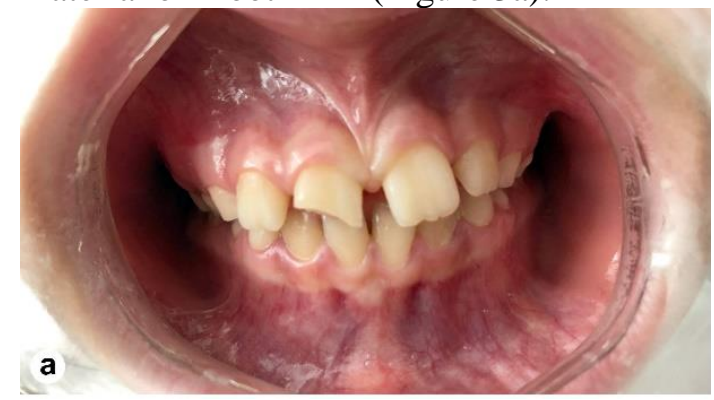

Figure 3a: Preoperative view of Case 3 showing a tooth fracture in Tooth \#11

There was no history of pain in the tooth and no sensitivity to percussion or palpation. Teeth \#11 and \#21 did not respond to electric or cold sensitivity tests. Radiographic examination revealed that both teeth had periapical radiolucency with open apices (Figure 3b).

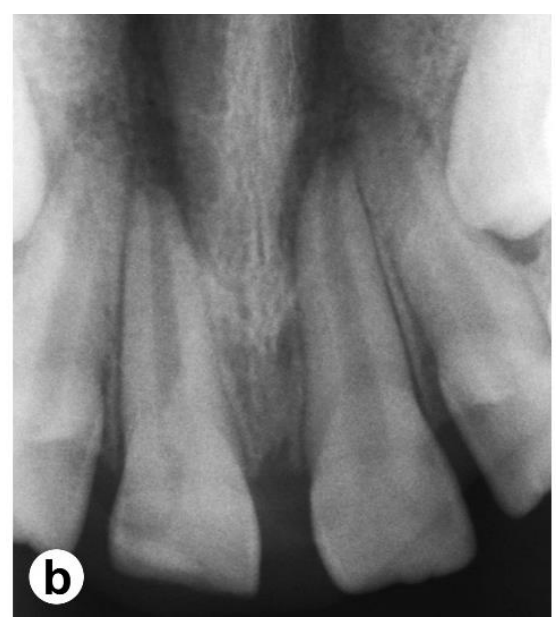

Figure 3b: Preoperative radiograph of Teeth \#11 and \#21 showing radiolucent lesions and open apices

The teeth were diagnosed with chronical apical periodontitis. After obtaining the informed consent, revascularization protocol was performed 
and PRF was used as a tissue scaffold (Figure 3c).

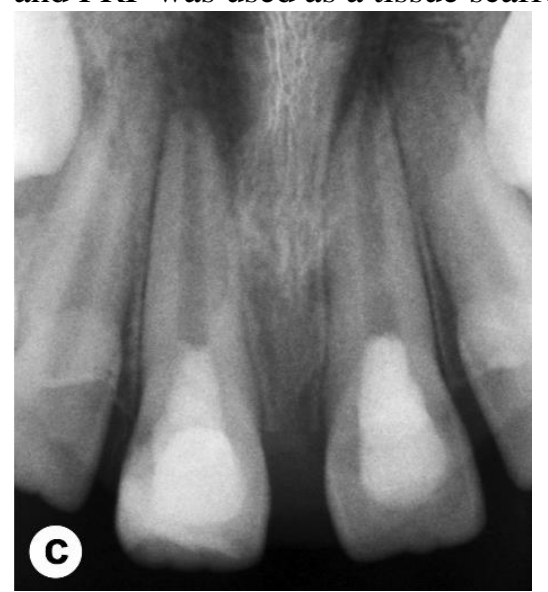

Figure 3c: Immediate post-treatment radiograph

At the end of the 24-month follow-up, it was observed that the periapical lesions were healed and root development was completed in both teeth, but a calcified tissue formed in the middle third of the root in Tooth \#11 (Figure 3d-h). Follow-up examinations are continuing.

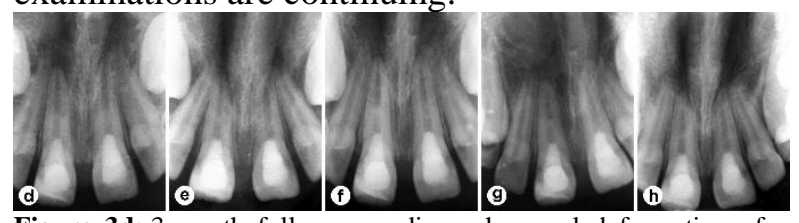

Figure 3d: 3-month follow-up radiograph revealed formation of a calcific barrier in the middle of the root at Tooth \#11

Figure 3e: 6-month follow-up radiograph

Figure 3f: 12-month follow-up radiograph

Figure 3g: At the 18-month follow-up, bony healing was evident with complete root maturogenesis

Figure 3h: 24-month follow-up radiograph

\section{DISCUSSION}

Revascularization/revitalization treatment has generally been applied for young permanent teeth with immature apex and pulp necrosis as well as in the presence of periradicular lesions. Regenerative endodontic treatments are mainly performed in teeth diagnosed with pulpal infections that occur due to trauma, caries or developmental anomalies (e.g. dens evaginatus). ${ }^{4}$ The requirements for regenerative endodontic treatment are the elimination of bacteria by effective canal disinfection, creation of a three-dimensional scaffold for the migration of stem/progenitor cells, and the prevention of bacterial reinfection with a good coronal seal. ${ }^{1-3}$

The bacteria remaining in the root canal after chemomechanical disinfection can be neutralized by root canal filling and a coronal sealing in conventional root canal treatments on mature teeth, whereas the clot formed in the root canal in revascularization treatments may promote residual bacteria to proliferate and develop bacterial biofilms. Therefore, long-term aseptic conditions should be provided in the root canal. ${ }^{19,20}$ However, the most important disadvantage of revascularization is that canal disinfection involves only the use of chemical substances without mechanical preparation. It is known that the presence of residual bacteria has a critical negative effect on the outcome of root development. ${ }^{20-22}$

In most studies of regenerative endodontic treatments, successful clinical and radiographic results have been reported with long-term followup. However, intraoperative protocols regarding the use of intracanal medicaments for disinfection varies. ${ }^{5,6,8,9,11,17,23}$ Low concentration of sodium hypochlorite, sterile saline solution and EDTA are generally used as irrigation agents and antibiotic mixtures or calcium hydroxide paste could be used for further disinfection. It is critical to maintain the viability of stem cells while ensuring adequate disinfection. ${ }^{20,21}$ In this case series, following the irrigation protocol in line with the recommendations of $\mathrm{AAE}^{4}$, double antibiotic paste that does not contain minocycline was preferred. A mixture of aerobic and anaerobic species of bacterial communities participates in the infection of the root canal system resulting in the subsequent periapical inflammation in immature permanent teeth with an open apex. Therefore, topical use of the combination of antibiotics disinfects the canal more effectively and at the same time reduces the possibility of developing antibiotic resistance. ${ }^{24}$ Researchers have warned that the use of high concentrations of antibiotics in regenerative endodontic therapy may be toxic to the living tissue. ${ }^{2,7}$ For these reasons, double antibiotic paste used in this case series was prepared in a form diluted at the rate of $0.1 \mathrm{mg} / \mathrm{ml}$. Successful treatment results in the long-term follow-up of the cases indicate that the necessary disinfection is provided.

Several studies have reported successful results in regenerative endodontic treatments using blood clots induced by apical bleeding. ${ }^{23,25}$ However, autologous platelet concentrates such as PRF and PRP could be used to create a tissue scaffold with or without blood clots. ${ }^{8,9,11,17,26}$ 
Although it has been reported that there is no difference in clinical success between the types of tissue scaffolds ${ }^{8,11,16}$, it has been determined in histological studies that autologous platelet concentrates give better results due to the high rate of released healing factors. ${ }^{2,10}$

PRF releases growth factors at a slower rate than PRP, contains more immune defense cells, provides good support for the calcium silicatecontaining agent to be placed on it, and does not require an external agent to coagulate. ${ }^{10,13,16} \mathrm{PRF}$ is also associated with slow and continuous increase in cytokine levels and contains more leukocytes compared to PRP and blood clot which makes PRF more effective in the presence of infection. ${ }^{10}$ In this case series, the use of PRF as a tissue scaffold was deemed appropriate due to the presence of acute infection in two teeth and the presence of a chronic long-term infection in two teeth.

In a meta-analysis comparing the clinical results of PRF, PRP and blood clot, it was reported that the rate of apex closure was higher in the PRP and PRF groups compared to the blood clot group after one-year follow-up. ${ }^{27}$ However, there are also cases where no obvious changes in root wall thickness, root length or apex closure was observed using PRF scaffold. ${ }^{17}$ It is considered that the severity of apical periodontitis and trauma, and the duration of pulp necrosis could reduce regeneration capacity as a result of the possibility of increased damage to the living tissues required for regeneration in case of long-term necrosis. ${ }^{28,29}$ Kahler et al. ${ }^{29}$ have reported that the apical closure was assessed as incomplete in $47.2 \%$ of cases in a clinical study carried out on 16 teeth. Considering the studies that claimed that the root growth potential depends on the viability of Hertwig epithelial root sheath cells, the success of the treatment depends on the history of trauma and duration of pulp necrosis. ${ }^{6,28,29}$ Although the use of PRF tissue scaffold is preferred to accelerate the healing, there is a long history of trauma and pulp necrosis in Case 2 depending on the periapical lesions observed, where there is no closure at apex after long-term follow-up.

The primary goal of the regenerative endodontic treatments is described to be the elimination of symptoms and the evidence of bone healing. The secondary goal is to obtain increased root wall thickness and/or increased root length which are defined as desired but not mandatory. It is stated that the presence of bone healing and disappearance of symptoms in the apical region is an acceptable success even without completed root development. ${ }^{3,4}$ Lin et $a l .{ }^{30}$ have reported that, whilst further root maturation is considered a successful outcome for teeth treated with revascularization/revitalization procedures, the primary objective should be the resolution of the signs and symptoms of apical periodontitis. It has also been reported that it is possible to deem the procedure a success by having the tooth act as a space maintainer until a suitable restorative option is available. Sensation of pain, the appearance of pathological findings in soft tissue or increased apical radiolucency are considered to be failure. ${ }^{1,3}$ In this case series, although root development was not completed in Case 2, no further treatment was needed and the patient was followed due to the absence of signs of a progressive infection in periapical tissues and no clinical symptoms.

In Case 3, a calcific barrier was observed in the middle third of the canal. This result is a complication reported in previous studies. ${ }^{8,31}$ It has been reported that in cases where pulp tissue is completely lost periodontal tissue cells from the apical opening may migrate into the canal and stem cells may be a pioneer in the formation of cementlike tissue. ${ }^{31}$ As the Biodentine material used in the treatment is mainly composed of calcium and silica, the release of $\mathrm{Ca}$ ion forms the basis of the bioactivity reactions of the material. This stimulates the formation of cell group in the osteogenic phenotype, and it might have resulted in the formation of the calcific barrier in the middle third of the canal. ${ }^{32}$

\section{CONCLUSIONS}

Although PRF has certain disadvantages such as need for special tools and blood collection from young patients, on the basis of long-term clinical and radiographic observations, it was found to be useful in constructing a scaffold for revascularization in the successful treatment of necrotic immature teeth with trauma history. However, prognosis of tooth can be attributed to many factors such as duration of pulp necrosis and 
viability of living tissues. Further clinical studies are needed to authorize the best tissue scaffold related to the pretreatment status of the tooth and the surrounding periapical tissues.

\section{CONFLICT OF INTEREST}

No potential conflict of interest relevant to this article was reported.

\section{ACKNOWLEDGEMENTS}

None.

$\ddot{O} \boldsymbol{Z}$

Rejeneratif endodontik tedavi, kök gelişimi tamamlanmamış ve pulpa nekrozu gerçekleşen genç daimi dişlerde kök gelişsiminin devamını sağlamak ve dişlerin uzun dönem prognozunu arttırmak amactyla uygulanan biyolojik temele dayall bir tedavi yaklaşımıdır. Bu vaka serisinde, nekrotik pulpalı 4 immatür dişte trombositten zengin fibrin (PRF) kullanllarak uygulanan rejeneratif endodontik tedavinin klinik ve radyografik takiplerinin sunulmas amaçlanmıştır. 18-24 aylik takipler sonucunda tedavi öncesinde görülen periapikal lezyonların tamaminin iyileştiği ve 4 dişin 3'ünde apikal kapanmanın sağlandiğl gözlemlenmiştir. Ancak kronik apikal periodontitis tanısı alan bir olguda 3. ayda kökün orta üçlüsünde kalsifiye doku oluşumu saptanmuştır. PRF'nin nekrotik dişlerin revaskülarizasyon protokolünde doku iskelesi olarak kullanımının başarll sonuçlar verdiği; ancak dişin prognozunun pulpa nekrozunun süresi, dişin tedavi öncesi durumu ve periapikal bölgedeki dokularin canlllı̆̆l gibi birç̧ok faktöre bağlı olduğu düşünülmektedir. Anahtar Kelimeler: Immatür diş, plateletten zengin fibrin, pulpa nekrozu, pulpa rejenerasyonu, doku iskelesi.

\section{REFERENCES}

1. Galler K. Clinical procedures for revitalization: current knowledge and considerations. Int Endod J 2016; 49: 926-936.

2. Kim SG, Malek M, Sigurdsson A, Lin LM, Kahler B. Regenerative endodontics: a comprehensive review. Int Endod J 2018; 51: 1367-1388.

3. Geisler TM. Clinical considerations for regenerative endodontic procedures. Dent Clin North Am 2012; 56: 603-626.

4. American Association of Endodontics. Clinical considerations for a regenerative procedure. [PDF on Internet]. [Updated 4 January 2018; cited 30 November
2020]. Available from: www.aae.org/specialty/clinicalresources/regenerative-endodontics.

5. Nosrat A, Li KL, Vir K, Hicks ML, Fouad AF. Is pulp regeneration necessary for root maturation? J Endod 2013; 39: 1291-1295.

6. Torabinejad M, Nosrat A, Verma P, Udochukwu O. Regenerative endodontic treatment or mineral trioxide aggregate apical plug in teeth with necrotic pulps and open apices: a systematic review and meta-analysis. J Endod 2017; 43: 1806-1820.

7. Digka A, Sakka D, Lyroudia K. Histological assessment of human regenerative endodontic procedures (REP) of immature permanent teeth with necrotic pulp/apical periodontitis: A systematic review. Aust Endod J 2020; 46: 140-153.

8. Bezgin $T$, Yılmaz AD, Celik BN, Kolsuz ME, Sönmez H. Efficacy of platelet-rich plasma as a scaffold in regenerative endodontic treatment. J Endod 2015; 41: 36-44.

9. Bakhtiar H, Esmaeili S, Fakhr Tabatabayi S, Ellini MR, Nekoofar MH, Dummer PM. Second-generation platelet concentrate (platelet-rich fibrin) as a scaffold in regenerative endodontics: a case series. J Endod 2017; 43: 401-408.

10. Chai J, Jin R, Yuan G, Kanter V, Miron RJ, Zhang Y. Effect of liquid platelet-rich fibrin and platelet-rich plasma on the regenerative potential of dental pulp cells cultured under inflammatory conditions: a comparative analysis. J Endod 2019; 45:1000-1008.

11. Ulusoy AT, Turedi I, Cimen M, Cehreli ZC. Evaluation of blood clot, platelet-rich plasma, platelet-rich fibrin, and platelet pellet as scaffolds in regenerative endodontic treatment: a prospective randomized trial. J Endod 2019; 45: 560-566.

12. Arango-Gómez E, Nino-Barrera JL, Nino G, Jordan F, Sossa-Rojas H. Pulp revascularization with and without platelet-rich plasma in two anterior teeth with horizontal radicular fractures: a case report. Restor Dent Endod 2019; 44.

13. Dohan DM, Choukroun J, Diss A, Dohan SL, Dohan AJJ, Mouhyi J, Gogly B. Platelet-rich fibrin (PRF): a second-generation platelet concentrate. Part I: technological concepts and evolution. Oral Surg Oral Med Oral Pathol Oral Radiol and Endod 2006;101:e37- 
e44.

14. Nagaveni NB, Poornima P, Joshi JS, Pathak S, Nandini DB. Revascularization of immature, nonvital permanent tooth using platelet-rich fibrin in children. Pediatr Dent 2015; 37: 1E-6E.

15. Ray HL Jr, Marcelino J, Braga R, Horwat R, Lisien M, Khaliq S. Long-term follow up of revascularization using platelet-rich fibrin. Dent Traumatol 2016;32:80-84.

16. Lv H, Chen Y, Cai Z, Lei L, Zhang M, Zhou R, Huang $X$. The efficacy of platelet-rich fibrin as a scaffold in regenerative endodontic treatment: a retrospective controlled cohort study. BMC Oral Health 2018; 18:1-8.

17. Kandemir Demirci G, Güneri P, Çalışkan M. Regenerative Endodontic Therapy with Platelet Rich Fibrin: Case Series. J Clin Pediatr Dent 2020; 44: 15-19.

18. Hotwani K, Sharma K. Platelet rich fibrin-a novel acumen into regenerative endodontic therapy. Restor Dent Endod 2014; 39:1-6.

19. Fouad AF, Verma P. Healing after regenerative procedures with and without pulpal infection. J Endod 2014; 40: S58-S64.

20. Verma P, Nosrat A, Kim JR, Price JB, Wang P, Bair E, Xu HH, Fouad AF. Effect of residual bacteria on the outcome of pulp regeneration in vivo. J Dent Res 2017; 96:100-106.

21. Cameron R, Claudia E, Ping W, Erin S, Ruparel NB. Effect of a residual biofilm on release of transforming growth factor $\beta 1$ from dentin. J Endod 2019; 45:11191125 .

22. Meschi N, Hilkens P,Van Gorp G, Strijbos O, Mavri dou A, Cadenas de Llano Perula M, Lambrichts I, Verbeken E, Lambrechts P. Regenerative endodontic procedures posttrauma: Immunohistologic analysis of a retrospective series of failed cases. J Endod 2019; 45: 427-434.

23. Cehreli ZC, Isbitiren B, Sara S, Erbas G.. Regenerative endodontic treatment (revascularization) of immature necrotic molars medicated with calcium hydroxide: a case series. J Endod 2011; 37: 1327-1330.

24. Rôças IN, Siqueira Jr JF. Detection of antibiotic resistance genes in samples from acute and chronic endodontic infections and after treatment. Arch Oral Biol 2013; 58: 1123-1128.

25. Flake NM, Gibbs JL, Diogenes A, Hargreaves KM, Khan AA. A standardized novel method to measure radiographic root changes after endodontic therapy in immature teeth. J Endod 2014; 40:46-50.

26. Jadhav GR, Shah N, Logani A. Comparative outcome of revascularization in bilateral, non-vital, immature maxillary anterior teeth supplemented with or without platelet rich plasma: A case series. J Conserv Dent 2013; 16:568.

27. Murray PE. Platelet-rich plasma and platelet-rich fibrin can induce apical closure more frequently than blood-clot revascularization for the regeneration of immature permanent teeth: a meta-analysis of clinical efficacy. Front Bioeng Biotechnol 2018; 6:139.

28. Nosrat A, Homayounfar N, Oloomi K. Drawbacks and unfavorable outcomes of regenerative endodontic treatments of necrotic immature teeth: a literature review and report of a case. J Endod 2012; 38:14281434.

29. Kahler B, Mistry S, Moule A, Ringsmuth AK, Case P, Thomson A, Holcombe T. Revascularization outcomes: a prospective analysis of 16 consecutive cases. J Endod 2014; 40: 333-338.

30. Lin LM, Kim SG, Martin G, Kahler B. Continued root maturation despite persistent apical periodontitis of immature permanent teeth after failed regenerative endodontic therapy. Aust Endod J 2018; 44: 292-299.

31. Song M, Cao Y, Shin SJ, Shon WJ, Chugal N, Kim RH, Kim E, Kang MK. Revascularization-associated intracanal calcification: assessment of prevalence and contributing factors. J Endod 2017; 43: 2025-2033.

32. Bonson $\mathrm{S}$, Jeansonne BG, Lallier TE. Root-end filling materials alter fibroblast differentiation. J Dent Res 2004; 83: 408-413. 